\title{
APPLICABILITY AND QUALITY ASSESSMENT OF THE SET OF EQUIPMENT IN THE PROJECT "POLYGON FOR PHYSICAL ACTIVITY OF SCHOOL-AGED CHILDREN“ IN PRIMARY SCHOOLS WITHOUT GYMNASIA
}

\author{
Slaven Krtalić1, Vitomir Spasović², Lana Kasumović1, Maja Lang Morović1, \\ Ljiljana Muslić ${ }^{1}$, and Sanja Musić Milanovićc ${ }^{1,3}$ \\ ${ }^{1}$ Croatian Institute of Public Health, Croatia \\ ${ }^{2}$ The association MOVEMENT (POKRET) - Active and Healthy, Croatia \\ ${ }^{3}$ University of Zagreb, School of Medicine, School of Public Health Andrija Štampar, Croatia
}

Original scientific paper

DOI: $10.26582 / \mathrm{k} .52 .1 .16$

\begin{abstract}
:
In 2015, 120 main primary schools in Croatia did not have a school gymnasium, and could not carry through the full-time compulsory Physical Education (PE) classes. To ensure regular physical exercise to all children and help teachers, the Croatian Institute of Public Health has implemented the project "Polygon for Physical Activity of School-Aged Children". This paper aims to present the usability and functionality assessment of the multipurpose kinesiology equipment set used in the Project in the primary schools without gymnasia based on the teachers' experience and appraisals in three independent assessment waves. Results show that after receiving the set the teachers perceived they had better conditions for teaching PE class and managed to fulfil PE curriculum goals and tasks. Students' motivation for physical education class also improved in some areas, as well as teachers' satisfaction with the conditions for and school investments in PE class. Most of the teachers perceived that the multipurpose kinesiology equipment set had the potential to improve the quality of PE class and to be used in other classes as well. According to the obtained data it could be assumed that this multipurpose kinesiology equipment set is a positive innovation in the teaching process and presents a strong potential for alleviating the spatial and material problems teachers in schools without gymnasia are experiencing in their work.
\end{abstract}

Key words: physical education and training, public health, schools, exercise promotion, students, teacher satisfaction

\section{Introduction}

Numerous studies have scientifically proven the role of physical activity (PA) as one of the vital health determinants from birth to adolescence (Ferraro, Gaudet, \& Adamo, 2012; Gísladóttir, Haga, \& Sigmundsson, 2013; Kodama, et al., 2009; Morton, Atkin, Corder, Suhrcke, \& van Sluijs, 2016). Despite this, children today are less physically active on the account of a sedentary way of life. Consequently, the incidence of overweight and obesity is increasing and negatively affects lifelong health (de Greeff, Bosker, Oosterlaan, Visscher, \& Hartman, 2018; Morton, et al., 2016). Positive childhood experiences have a strong impact on forming healthy life habits and preserving health (Goldfield, Harvey, Grattan, \& Adamo, 2012; Jureša \& Petrović, 2012; WHO, 2004).
Because school-aged children spend almost half of their awake time at school, schools are an important environment for PA promotion and reduction of sedentary behaviours (Langford, Bonell, Jones, \& Campbell, 2015; Langford, et al., 2015). The Physical Education (PE) class is significant for students' health since it necessitates their active participation. PE differs considerably from other classes specifically in terms of material, technical and weather conditions of teaching. The importance of PE, in the sphere of the education system, is that students are being taught how to move properly and to use the acquired motor skills to overcome obstacles in space. Besides the individual characteristics of a teacher, issues such as lack or non-availability of a gymnasium, inadequate and incomplete facilities and equipment play a significant role in fulfilling a 
curriculum and accomplishing the PE goals (Kul, Yilmaz, \& Yasartürk, 2018; Tsangaridou, 2017).

Lacking material conditions, i.e. the lack of a gymnasium and quality exercise equipment, is considered to be the foremost issue that influences the work of PE teachers (Kul, et al., 2018; Pažur, 2019). According to the Pedagogical Standard of Primary Education in the Republic of Croatia (MSES, 2008b), PE classes can be held both outdoors, weather conditions permitting, i.e. on the playground, athletic tracks and fields, pitches, free green areas, in outdoor swimming pools, etc., and indoors, in gymnasia, fitness and aerobic centres, swimming pools, etc. Additionally, various devices, visual, auditory, audio-visual, and textual assets and technical aids and equipment can be used while teaching PE. However, the actual situation with PE teaching in primary and secondary schools in the Republic of Croatia is somewhat different from the standard. A large number of schools, both main and peripheral, have no gymnasium or outdoor facilities. To help overcome the spatial and material obstacles brought by the lack of gymnasia and to ensure equal opportunities to all students to regularly attend PE and help teachers teach PE to students in grades one through four in Croatia, the Croatian Institute of Public Health (CIPH) has designed a project called "Polygon for Physical Activity of School-Aged Children" (Polygon).

\section{Description of the Polygon Project}

In the school year 2014/2015, there were 2055 primary schools in the Republic of Croatia, 860 main and 1,195 peripheral schools (Croatian Bureau of Statistics, 2016). Of the 860 main primary schools, 120 of them had no or limited access to a gymnasium. Consequently, these schools could not carry out the full-time compulsory PE of 45 minutes three times per week for grades one to three and 45 minutes two times per week for grades four to eight (MSES, 2006). The Polygon project was implemented to ensure the fundamental logistics for teaching mandatory PE in main primary schools without gymnasia and, thereby, reinforce the habit of regular PA in students as one of the key factors in childhood obesity and overweight prevention. Namely, childhood obesity and overweight is a significant risk factor for developing any of the leading non-communicable diseases, responsible for about $90 \%$ of all deaths in Croatia (Stevanović, Capak, \& Benjak, 2016).

The basic tool used in the Polygon project that helps class teachers achieve educational goals and tasks is a carefully designed multipurpose set of kinesiological, physical exercise aids (Set), consisting of 25 easily assembled and disassembled elements, adaptable to various indoor or outdoor locations. The elements of the Set were more thoroughly described elsewhere (CIPH, 2016).
As part of the Polygon project, the CIPH has, with the help of the Ministry of Health, secured the funds for the procurement of 120 Sets to be donated to all main primary schools without gymnasia in the Republic of Croatia. Additional assistance was offered in the form of a Manual (Krtalić, Pejnović Franelić, \& Delaš, 2015) tailored to the practical needs of class teachers and kinesiologists to help them find creative solutions to existing implementation restrictions and to help them achieve the objectives of PE. The Manual is, likewise, intended as secondary literature for teaching associates, students and all others who work in any form of physical education. Furthermore, the education of three-member school teams participating in the Polygon project was organized in collaboration with the Ministry of Science, Education and Sport, and the Education and Teacher Training Agency. After the education and the distribution of Sets, the schools were contacted to see if they required any additional training in the use of the Set. None of the schools sought any further assistance. Since the Set was used for the first time within the Project with the aim of enabling regular PA and full time compulsory PE in schools without gymnasia, before evaluating the whole Project, it was important to assess its usability and functionality as well as some aspects of teachers' experience related to the usage of the multipurpose kinesiology equipment set in primary schools without gymnasia.

\section{Objective}

The objective of this paper is to present an assessment of the usability and functionality of the Set in primary schools without gymnasia based on some aspects of teachers' experience in using the Set. The evaluation included an assessment and comparison of the following dimensions of the Set:

- Possibilities for PE implementation in schools without gymnasia before and after the introduction of the Set,

- Attributes of PE implementation in schools without gymnasia before and after receiving the Set (teachers' interest in and satisfaction with conditions for teaching PE, students' motivation for PE, and suitability of the exercise, kinesiology equipment for the youngest students),

- Functionality and applicability of the Set within $\mathrm{PE}$ and other classes.

\section{Methods}

The teachers' perceptions and experiences in relation to the Set objectives were assessed by inviting the teachers who were using the Set in 120 schools without gymnasia to participate in an online survey. Each of 120 participating schools had a three-member team comprised of two class teachers and one PE teacher, a kinesiologist, making 
a total target sample of 360 teachers, i.e. 240 class and 120 PE teachers. These teachers were the ones who used the Set primarily in PE but also within other school activities.

Data were collected with three online questionnaires specifically designed for the purpose of this evaluation, and each administered at a different time point:

1. Questionnaire 1(Q1) assessed the conditions for teaching PE and experiences in teaching PE before the introduction of the Set,

2. Questionnaire $2(\mathrm{Q} 2)$ assessed the conditions for teaching PE and experiences in teaching PE after the introduction of the Set, and

3. Questionnaire $3(\mathrm{Q} 3)$ assessed the functionality and applicability of the Set.

The questionnaires were anonymous with no possibility to reveal the identity or the function of respondents. The questionnaires consisted of different types of questions: Likert scale type questions, yes-or-no questions, multiple-choice answers, or open-ended questions. All targeted teachers received the invitation and the online questionnaires via an e-mail link with accompanying instructions. The participation was voluntary, according to ethical principles. Q1 was administered at the beginning of the second semester, and Q2 and Q3 at the end of the second semester of the school year $2015 / 2016$. Due to the complete anonymity of the online survey, the responses given at different time points could not be paired. The characteristics of the respondents on all three questionnaires are presented in Table 1.

In all three subsamples, the respondents were mostly female teachers. The majority of them was between 40 and 49 years of age and had between 16 and 25 years of working experience.
The possibility of PE implementation in schools without gymnasia after the introduction of the Set was assessed by comparing teachers' experiences and perceptions of the conditions and possibilities to teach PE in comparison to other schools in the community before (Q1) and after receiving the Set (Q2). Additionally, the degree to which it was possible to teach full-time compulsory PE in indoor school areas before and after receiving the Set was also assessed by comparing responses on Q1 and Q2.

Different attributes of the PE implementation experience in schools without gymnasia after receiving the Set were assessed with the following: teachers' self-assessment of their level of interest in teaching PE and satisfaction with conditions for teaching PE, assessment of students' motivation for $\mathrm{PE}$ and the suitability of school exercise equipment for the youngest students before and after receiving the Set, gained through Q1 and Q2.

The functionality and applicability of the Set within PE and other classes were assessed with Q3 through teachers' assessment of the Set's suitability for improving conditions to teach PE as well as other classes, reaching PE curriculum objectives and tasks, and through teacher's assessment of the students' responses to using the Set.

\section{Statistical analysis}

Collected data were processed using methods of descriptive statistics. Relative data frequencies were analysed for categorical variables. Data samples were treated as two independent data samples - a sample before receiving the Set and the sample after receiving the Set, rather than dependent samples of participants, because the responses could not be matched. The difference between the observed

Table 1. Characteristics of respondents to Questionnaire 1, Questionnaire 2, and Questionnaire 3

\begin{tabular}{|c|c|c|c|}
\hline & Questionnaire $1(\mathrm{~N}=190)$ & Questionnaire $2(\mathrm{~N}=138)$ & Questionnaire $3(\mathrm{~N}=111)$ \\
\hline Variable & $\%(N)$ & $\%(N)$ & $\%(\mathrm{~N})$ \\
\hline \multicolumn{4}{|l|}{ Sex } \\
\hline Female & $67.9(129)$ & $82.6(114)$ & $93.7(104)$ \\
\hline Male & $11.1(21)$ & $6.6(9)$ & $6.3(7)$ \\
\hline \multicolumn{4}{|c|}{ Age (years) } \\
\hline $23-29$ & $9.5(18)$ & $5.8(8)$ & $7.2(8)$ \\
\hline $30-39$ & $24.2(46)$ & $28.3(39)$ & $31.5(35)$ \\
\hline $40-49$ & $31.1(59)$ & $38.4(53)$ & $42.3(47)$ \\
\hline $50-59$ & $12.6(24)$ & $16.7(23)$ & $18.9(21)$ \\
\hline$>60$ & $1.6(3)$ & $0.0(0)$ & $0.0(0)$ \\
\hline \multicolumn{4}{|c|}{ Work experience (years) } \\
\hline$\leq 5$ & $12.2(23)$ & $12.2(17)$ & $15.3(17)$ \\
\hline $6-15$ & $24.3(46)$ & $25.9(36)$ & $27(30)$ \\
\hline $16-25$ & $28.5(54)$ & $37.6(52)$ & $41.4(46)$ \\
\hline$\geq 26$ & $13.8(26)$ & $12.8(18)$ & $15.3(17)$ \\
\hline
\end{tabular}


means from the sample before receiving the Set and the sample after receiving the Set was compared using $t$-test. Results were analysed at 0.05 level of significance. The data was statistically processed using the IBM SPSS Statistics software, ver. 23.0, 2015. (ID: 729038) (IBM Corp, 2015).

\section{Results}

The results presented in Table 2 show that most teachers, $74.11 \%$ of them, moved the Set between classrooms, or occasionally assembled it in various school areas, while the remaining teachers had the Set permanently placed in a specific place. The use of the Set was largely in line with the teacher's beliefs on the optimal location of the Set in their school given the available spatial and technical conditions. Results show that $55.86 \%$ of teachers believed the optimal use of the Set in their school was to assemble it, as needed, in various school areas (the lobby, exercise area, schoolyard, etc.) or relocate it between classrooms, while $38.74 \%$ thought the best option was to have it assembled in a permanent place. Data on the frequency of the Set use in PE, show that $85.59 \%$ of teachers regularly used the Set, once to three times per week; $28 \%$ of teachers encountered difficulties in the application of the Set, most commonly in assembly and disassembly.

As presented in Figure 1, over two thirds of the questioned teachers, $67.66 \%$ of them, perceived having poorer conditions for teaching $\mathrm{PE}$ in comparison to other schools in the community before receiving the Set, as did only $28.57 \%$ of the questioned teachers after obtaining the Set. Data in Figure 2 shows that most teachers, $73.81 \%$ of them questioned after receiving the Set, found that they could fulfil between two thirds and the whole compulsory PE curriculum indoors, while before receiving the Set, $80.72 \%$ of the questioned teachers thought that they could fulfil two thirds or less of compulsory PE curriculum indoors.

Results presented in Table 3 show a statistically significant difference between before and after receiving the Set in the attributes of PE implementation in schools without gymnasia. Overall, results show that students were generally motivated for PE. When comparing results before and after the introduction of the Set, we found a significant difference in teachers' responses on statements related to students' reactions to PE implementation; "My students love PE", "Students are motivated to exercise with school equipment" and "My students prefer having PE outdoors" but not on the "My students are generally motivated for PE". Also, a significant difference was found between the opinions of teachers questioned before and after receiving the Set on the adjustment of school equipment to the youngest students. Finally, regarding teachers' satisfaction, we found that the group questioned after receiving the Set was more satisfied with the conditions for teaching PE and with school investments in PE, but not more interested in applying new teaching methods in comparison to the group questioned before receiving the Set.

The data on functionality and applicability of the Set within PE and other classes, presented in

Table 2. Actual and optimal school areas where the Set is located

\begin{tabular}{lccccccc}
\hline & $\begin{array}{c}\text { Permanently } \\
\text { placed in a } \\
\text { classroom } \\
(\mathrm{N})\end{array}$ & $\begin{array}{c}\text { Permanently } \\
\text { placed in a } \\
\text { specific place } \\
(\mathrm{N})\end{array}$ & $\begin{array}{c}\text { Permanently } \\
\text { placed in an } \\
\text { exercise area } \\
(\mathrm{N})\end{array}$ & $\begin{array}{c}\text { Relocated } \\
\text { between } \\
\text { classrooms } \\
(\mathrm{N})\end{array}$ & $\begin{array}{c}\text { Used in various } \\
\text { school areas } \\
(\mathrm{N})\end{array}$ & $\begin{array}{c}\text { Other } \\
(\mathrm{N})\end{array}$ & $\begin{array}{c}\text { Total } \\
\text { Optimal }\end{array}$ \\
\hline Actual & 5 & 14 & 10 & 27 & 56 & 10 & 111 \\
\hline
\end{tabular}

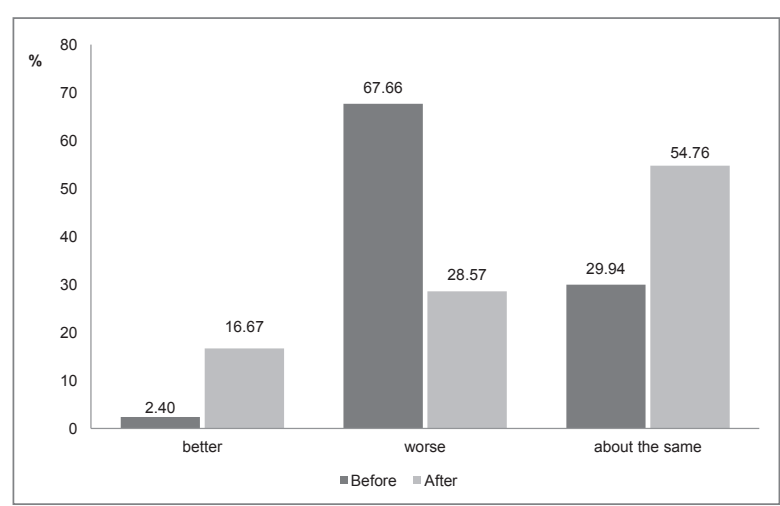

Figure 1. Teachers' assessment of conditions and possibility of teaching Physical Education class in schools without gymnasia before and after receiving the Set.

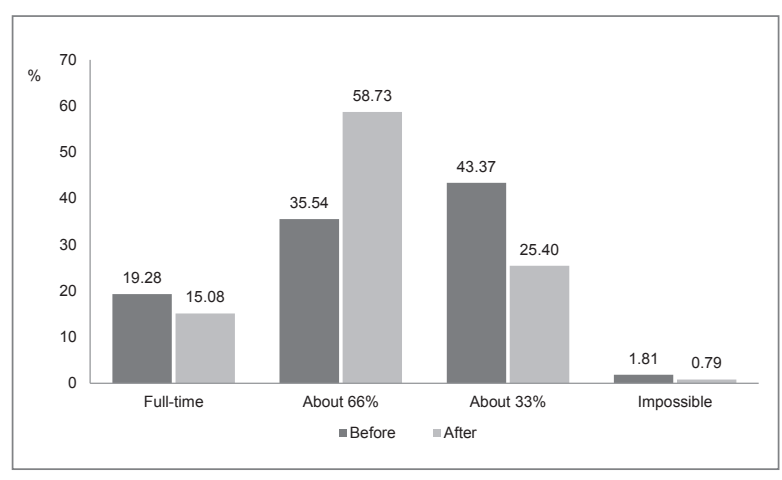

Figure 2. Teachers' assessment of the degree to which it was possible to teach full-time compulsory Physical Education class in indoor school areas in schools without gymnasia before and after receiving the Set from the Polygon project. 
Table 3. Assessment of different attributes of the PE implementation in schools without gymnasia before and after receiving the Set

\begin{tabular}{|c|c|c|c|c|c|c|c|c|c|}
\hline & & Before & & & After & & & & \\
\hline & $\mathrm{N}$ & M & $(\mathrm{SD})$ & $\mathrm{N}$ & M & (SD) & $t$ & $\mathrm{DF}$ & $\mathrm{p}$ \\
\hline My students love PE. & 165 & 4.73 & $(.69)$ & 126 & 4.90 & $(0.33)$ & 2.534 & 289 & $.0118^{*}$ \\
\hline $\begin{array}{l}\text { Students are motivated to exercise with the } \\
\text { school equipment. }\end{array}$ & 166 & 3.65 & $(1.03)$ & 126 & 4.49 & $(0.68)$ & 7.942 & 290 & $<.0001^{* * *}$ \\
\hline My students prefer having PE outdoors. & 167 & 4.10 & $(.99)$ & 126 & 4.36 & $(.85)$ & 2.373 & 291 & $.0183^{*}$ \\
\hline $\begin{array}{l}\text { My students are generally motivated for } \\
\text { physical activity. }\end{array}$ & 166 & 4.55 & $(.70)$ & 126 & 4.65 & $(.51)$ & 1.387 & 290 & .1667 \\
\hline $\begin{array}{l}\text { Sports equipment in my school is adapted } \\
\text { to even the youngest students. }\end{array}$ & 166 & 2.81 & $(1.09)$ & 126 & 3.90 & $(1.05)$ & 8.621 & 290 & $<.0001^{* * *}$ \\
\hline $\begin{array}{l}\text { I am content with the conditions for } \\
\text { teaching PE. }\end{array}$ & 166 & 2.47 & $(1.08)$ & 126 & 2.98 & $(1.28)$ & 3.979 & 290 & $.0001^{* \star *}$ \\
\hline $\begin{array}{l}\text { I am not satisfied with the school } \\
\text { investments in the PE. }\end{array}$ & 165 & 3.90 & 1.04 & 126 & 3.61 & 1.08 & -2.285 & 289 & $.0230^{*}$ \\
\hline $\begin{array}{l}\text { I am interested in applying new teaching } \\
\text { methods. }\end{array}$ & 166 & 4.54 & $(.71)$ & 126 & 4.60 & .55 & .693 & 290 & .4890 \\
\hline
\end{tabular}

Note. PE - Physical Education class, $\mathrm{N}$ - number of participants, $\mathrm{M}$ - arithmetic mean, $\mathrm{SD}$ - standard deviation, $\mathrm{t}$ - $\mathrm{t}$-statistics, $\mathrm{DF}-$ degrees of freedom, $p$ - probability, ${ }^{*}-$ significant at $\leq .05$ level, ${ }^{* *}-$ significant at $\leq .01$ level, ${ }^{* * *}-$ significant at $\leq .001$ level.

Table 4. Perception of functionality and applicability of the Set

\begin{tabular}{lccccc}
\hline & Not at all (\%) & Partly (\%) & Fairly (\%) & Highly (\%) & Fully (\%) \\
\hline My students liked the Set. & .00 & .90 & 4.50 & 11.71 & 82.88 \\
$\begin{array}{l}\text { The Set improves possibilities to teach PE. } \\
\begin{array}{l}\text { The Set improves capacity to reach PE curriculum } \\
\text { objectives and tasks. }\end{array}\end{array} \quad .00$ & .00 & 9.91 & 47.75 & 42.34 \\
\begin{tabular}{l} 
The Set is suitable for teaching other classes. \\
\hline
\end{tabular} & .90 & 5.41 & 37.84 & 42.34 & 13.51 \\
\hline
\end{tabular}

Note. PE - Physical Education class.

Table 4, show that the majority of teachers, $90.09 \%$ of them, saw the Set's potential to highly or fully likely help improve the quality of PE. Most of them, $81.08 \%$, also responded that the Set is highly or fully likely to help meet all PE objectives and tasks set by the National PE Curriculum. Additionally, $94.59 \%$ of teachers agreed that the students liked the Set and $99.10 \%$ responders recognized the Set's applicability to other classes.

\section{Discussion and conclusion}

The aim of this paper was to present an assessment of the usability and functionality of the Set in primary schools without gymnasia. The results showed that most teachers, $86 \%$ of them, used the Set regularly, once to three times per week and were well acquainted with it. Due to the teachers' experience with using the Set, their perspective on its applicability is relevant for further implementation and strengthening of the Polygon project.

Overall, regarding the possibility of implementation of PE in schools without gymnasia, the Set brought a positive change to school conditions and possibilities for teaching PE in the indoor school areas. The dramatic change in modern life and its many demands brought up recommendations for PA for health, which for children aged 6-18 years equal a minimum of 60 minutes of moderate to vigorous physical activity per day (WHO, 2010). Despite this recommendation, the Republic of Croatia, in the National Curriculum for Primary Schools, mandates three school-hours of PE per week in the first three grades and only two school-hours in the fourth grade of primary school. Also, according to the Pedagogical Standard of Primary Education in the Republic of Croatia (MSES, 2008b), gymnasia are required for teaching PE to primary school students in grades five through eight (MSES, 2008a). Due to restricted resources and a lack of investments and funding, many schools have poor spatial, material, and technical conditions, and do not have school gymnasia. Due to that, there is a risk that children would not to be able to reach either full-time PE curriculum, or PA recommendations for health. Supplying schools with resources in 
form of the Set, additional equipment required for teaching PE, through the Polygon project, proved to be beneficial for the administration of PE in over two thirds of main schools lacking gymnasia. The results obtained by comparing teachers' assessment regarding the conditions before and after introducing the Set suggest that the Set has contributed to improving the quality of $\mathrm{PE}$ and providing the capacity for teaching PE in schools without gymnasia. Given that the possibility to administer PE in schools without gymnasia gives students additional time spent in moderate to vigorous PA and not sedentary activities, it can be argued that the purpose of the Set might also be related to health outcomes and goes above and beyond its function to assist in the implementation of PE (S. Chen, Kim, $\&$ Gao, 2014), which should be further explored in the future.

Another observed change after introducing the Set was related to different attributes of PE in schools without gymnasia. First of all, a significant change was observed in regard to teachers' perception of students' motivation for PE. When assessing motivational or other PE attributes after receiving the Set, teachers reported, on average, that students loved PE, were motivated to exercise with the school equipment and preferred having PE outdoors more in comparison to before receiving the Set. According to the "Copenhagen Consensus Conference 2016: children, youth, and physical activity in schools and during leisure time", Theme 3: Physical activity in children and youth: engagement, motivation, psychological well-being, "an autonomy supportive, mastery focused and caring/socially supportive environment, positively influences children's and youths' self-determined motivation, physical activity behaviour and holistic well-being" (Bangsbo, et al., 2016). Students' enjoyment in PE is related to meaningful choice, i.e. the choice that is aligned with and reflects student's goals, interests and values (Assor, Kaplan, \& Roth, 2002). It may be argued that introducing a new set of equipment that is interesting to students, offers a variety of materials and activities to choose from, and at the same time makes them and their teachers feel competent is the reason for the observed increase in students' affinity to PE after the introduction of the Set (Domville, Watson, Richardson, \& Graves, 2019; Xiang, McBride, \& Gao, 2011). Also, Chen and associates found that students' enjoyment and interest in PE were related to novelty, challenge, exploration intention, and attention demand dimensions, all features brought by the new Set (A. Chen \& Darst, 2001; A. Chen \& Wang, 2017).

An additional change brought by the Set was related to conditions for PE in terms of equipment and school investments in PE. After receiving the Set, teachers were more satisfied with school conditions and investments in PE. The possibilities for creative solutions in the administration of PE and developing motor skills in children in schools are abundant but depend on the spatial conditions of the school. Not having either equipment or school investments presents an obstacle that teachers from schools without gymnasia face on a daily basis. Resource adequacy influences job satisfaction, hence a lack of facilities and equipment might consequently make teachers less content with their job (Aldridge \& Fraser, 2016). Receiving the equipment for PE contained in the Set improves conditions for administering PE, thus making the teachers more satisfied and less burned-out (Kroupis, Kouli, $\&$ Kourtessis, 2019). Furthermore, after receiving the Set, teachers perceived that their school equipment was adapted to the youngest students. This notion is especially important from the developmental perspective. Children, at the age of entering the school are at the stage when they are developing basic movement skills. These skills form the foundation of almost all later sporting and physical activities and children with strong movement skills are more likely to be active adults (Bailey, 2006). Strong fundamental movement skills also contribute to the overall development including healthy weight, cognitive and academic skills (Barnett, et al., 2016). Going to school in an environment that is, due to a lack of gymnasia, restricted in terms of physical activity, may pose a great threat to the development of basic movement skills. Therefore, the Set, being perceived as suitable for the youngest students, can help to create opportunities for the youngest children to be more active and develop strong basic movement skills that will contribute to their overall development.

After receiving the Set, data on the teachers' interest in applying new teaching methods in PE did not differ significantly. One may argue that the reason for this was that the teachers did not perceive the Set as a novel teaching method and felt comfortable using it.

Key factors for the Set applicability that may affect the enthusiasm and satisfaction of teachers are other spatial and technical school conditions in schools without gymnasia, as well as the choice of location of the Set (McCaughtry, et al, 2006).

From the standpoint of functionality, besides its overall contribution to the administration of PE and students' interest, teachers found that the Set was also suitable for teaching other classes. Using the Set to integrate PA into the classroom will result in less time spent sedentary and add to the time spent in PA (Beighle, Erwin, Webster, \& Webster, 2019). Besides that, using PA in the classroom will also enable students to think more broadly about the lesson being learned as well as experience alternative pathways for learning, i.e. motor and sensory, which is the optimal way of learning emphasized by leading educational scholars such as Howard 
Gardner or Maria Montessori (Gardner, 2006; Montessori, 1995).

Regarding the placement of the Set, more than half of teachers agreed that the optimal use of the Set was to either assemble it in different school locations or to move it from classroom to classroom. When placing the Set this way, not only can PE be more easily administered in limited spatial conditions, but also, the Set can be used for other purposes as well. Having the Set located in an approachable location for students to use it during recess might increase students' active time during recess and contribute to overall daily time spent in PA (Delidou, Matsouka, \& Nikolaidis, 2015).

The present study is the first study in Croatia to identify enhanced opportunities for PE time in indoor school areas, thus ensuring teacher's uninterrupted work, regardless of the weather, and ascertaining the functionality and applicability of the Set. These results will serve as the first step towards a broader evaluation of the entire Polygon project that will illustrate its public health impact.

The obtained results, however, should be perceived in line with several limitations to this study. The first one is related to the sample. Although all three subsamples consisted of teachers from the same schools, we could not match the participants, so the samples were treated as independent measurement samples. Second, a similar questionnaire ought to be administered after a longer period of using the equipment in order to gather more information on the sustainability and applicability of the equipment and more detailed information of the use of the set in different circumstances, i.e. in different parts of PE, during teaching other classes, during extracurricular activities, and during recess. In future research, including students' experiences and perception of the Set would additionally contribute to the evaluation of this toolkit, designed to enable students' PA in schools with limited resources, as well as including longitudinal data such as in a form of diary to track the implementation of Set more precisely. Also, objective measures should also be incorporated into the evaluation to detect improvement in objectively measured movement skills with and without the Set.

Conclusively, the results of this study have shown that using the Set from the Polygon project is likely to help minimize or solve the problem of implementing all compulsory PE in primary schools without gymnasia. School team members have acknowledged the opportunity and advantages of the new tool and expressed their satisfaction with it. Teaching and motivating students to exercise in school is a challenge, as well as a task, for every teacher (Mawer, 2014). Reinforcing the habit of daily PA and helping students to internalize it is one of the pivotal prerequisites to preserving children's health and preventing unhealthy life styles (S. Chen, et al., 2014; Lonsdale, et al., 2013). Teachers, as leaders of PE classes, have a great opportunity to positively affect a multitude of personal traits, capacities and qualities of their students (Bailey, 2006). In an organized attempt to overcome the consistently overwhelming challenges of encouraging children to be more active and less sedentary, this project is a novel opportunity for teaching and a concrete opportunity for mitigating the existing spatial and material challenges many schools are facing. Comparative advantages of this particular Set give schools without gymnasia an opportunity to improve the quality of their PE and to motivate students to be more active and contribute to their lifelong health. Specifically, the financial advantage of the Set should not be disregarded: investing into the Set in question is a way more cost-effective in comparison to building a new gymnasium. In other words, poor finances and the inability to build enough gymnasia impedes the implementation of full-time compulsory PE. This can partly be solved by using the Set to ensure children's regular PA inside and outside school grounds.

\section{References}

Aldridge, J.M., \& Fraser, B.J. (2016). Teachers' views of their school climate and its relationship with teacher selfefficacy and job satisfaction. Learning Environments Research, 19(2), 291-307. doi: 10.1007/s10984-015-9198-x

Assor, A., Kaplan, H., \& Roth, G. (2002). Choice is good, but relevance is excellent: Autonomy-enhancing and suppressing teacher behaviours predicting students' engagement in schoolwork. British Journal of Educational Psychology, 72(2), 261-278. doi: 10.1348/000709902158883

Bailey, R. (2006). Physical education and sport in schools: A review of benefits and outcomes. Journal of School Health, 76(8), 397-401. doi: 10.1111/j.1746-1561.2006.00132.x

Bangsbo, J., Krustrup, P., Duda, J., Hillman, C., Andersen, L.B., Weiss, M., ..., \& Elbe, A.M. (2016). The Copenhagen Consensus Conference 2016: Children, youth, and physical activity in schools and during leisure time. British Journal of Sports Medicine, 50(19), 1177-1178. doi: 10.1136/bjsports-2016-096325 
Barnett, L.M., Stodden, D., Cohen, K.E., Smith, J.J., Lubans, D.R., Lenoir, M., .., \& Morgan, P.J. (2016). Fundamental movement skills: An important focus. Journal of Teaching in Physical Education, 35(3), 219-225. doi: 10.1123/ jtpe.2014-0209

Beighle, A., Erwin, H., Webster, C.A., \& Webster, Mi.A. (2019). Physical activity during school. In R. Carson \& C.A. Webster (Eds.), Comprehensive school physical activity programs: Putting evidence-based research into practice (pp. 99-110). Champaign, IL: Human Kinetics.

Chen, A., \& Darst, P.W. (2001). Situational interest in physical education: A function of learning task design. Research Quarterly for Exercise and Sport, 72(2), 150-164. doi: 10.1080/02701367.2001.10608945

Chen, A., \& Wang, Y. (2017). The role of interest in physical education: A review of research evidence. Journal of Teaching in Physical Education, 36(3), 313-322. doi: 10.1123/jtpe.2017-0033

Chen, S., Kim, Y., \& Gao, Z. (2014). The contributing role of physical education in youth's daily physical activity and sedentary behavior. BMC Public Health, 14(1), 1-7. doi: 10.1186/1471-2458-14-110

CIPH - Croatian Institute of Public Health. (2016). Polygon for Physical Activity of School-aged Children (in Croatian). Retrieved from https://www.hzjz.hr/wp-content/uploads/2016/10/POLIGON-ZA-TJELESNU-AKTIVNOST$\%$ C5\%A0KOLSKE-DJECE.pdf on May 11, 2019.

Croatian Bureau of Statistics. (2016). Basic Schools End of 2014/2015 School Year and Beginning of 2015/2016 School Year. Retrieved from https://www.dzs.hr/default_e.htm on May 10, 2019.

de Greeff, J.W., Bosker, R.J., Oosterlaan, J., Visscher, C., \& Hartman, E. (2018). Effects of physical activity on executive functions, attention and academic performance in preadolescent children: A meta-analysis. Journal of Science and Medicine in Sport, 21(5), 501-507. doi: 10.1016/j.jsams.2017.09.595

Delidou, E., Matsouka, O., \& Nikolaidis, C. (2015). Influence of school playground size and equipment on the physical activity of students during recess. European Physical Education Review, 22(2), 215-224. doi: $10.1177 / 1356336 X 15598790$

Domville, M., Watson, P.M., Richardson, D., \& Graves, L.E.F. (2019). Children's perceptions of factors that influence PE enjoyment: A qualitative investigation. Physical Education and Sport Pedagogy, 24(3), 207-219. doi: 10.1080/17408989.2018.1561836

Ferraro, Z., Gaudet, L., \& Adamo, K. (2012). The potential impact of physical activity during pregnancy on maternal and neonatal outcomes. Obstetrical and Gynecological Survey, 67(2), 99-110. doi: 10.1097/OGX.0b013e318242030e

Gardner, H. (2006). Changing minds: The art and science of changing our own and other peoples minds. Boston, MA: Harvard Business Review Press.

Gísladóttir, T., Haga, M., \& Sigmundsson, H. (2013). Physical fitness measures among adolescents with high and low motor competence. SAGE Open, 3(3). doi: 10.1177/2158244013500282

Goldfield, G.S., Harvey, A., Grattan, K., \& Adamo, K.B. (2012). Physical activity promotion in the preschool years: A critical period to intervene. International Journal of Environmental Research and Public Health, 9(4), 13261342. doi: 10.3390/ijerph9041326

Jureša, V., \& Petrović, D. (2012). Behavioral pattern of overweight and obese school children. Collegium Antropologicum, 36(1), 139. doi: 10.5671/ca.2012361s.139

Kodama, S., Saito, K., Tanaka, S., Maki, M., Yachi, Y., ..., \& Sone, H. (2009). Cardiorespiratory fitness as a quantitative predictor of all-cause mortality and cardiovascular events. Journal of American Medical Association, 301(19), 2024-2035. doi: 10.1001/jama.2009.681

Kroupis, I., Kouli, O., \& Kourtessis, T. (2019). Physical education teacher's job satisfaction and burnout levels in relation to school's sport facilities. International Journal of Instruction, 12(4), 579-592. doi: 10.29333/iji.2019.12437a

Krtalić, S., Pejnović Franelić, I., \& Delaš, M. (2015). Poligon za tjelesnu aktivnost školske djece. [Polygon/Obstacle course for physical activity of school-aged children. In Croatian.] Retrieved from https://www.hzjz.hr/wp-content/ uploads/2015/11/PRIRUCNIK-final.pdf on May 11, 2019.

Kul, M., Yilmaz, S.H., \& Yasartürk, F. (2018). An investigation of professional problems of physical education and sports teachers and effects of these problems on their performance and motivation. Higher Education Studies, 8(4), 23. doi: 10.5539/hes.v8n4p23

Langford, R., Bonell, C., Jones, H., \& Campbell, R. (2015). Obesity prevention and the Health promoting Schools framework: Essential components and barriers to success. International Journal of Behavioral Nutrition and Physical Activity, 12(1), Article No. 15. doi: 10.1186/s12966-015-0167-7

Langford, R., Bonell, C., Jones, H., Pouliou, T., Murphy, S., Waters, E., ..., \& Campbell, R. (2015). The World Health Organization's Health Promoting Schools framework: A Cochrane systematic review and meta-analysis. $B M C$ Public Health, 15(1), Article No. 130. doi: 10.1186/s12889-015-1360-y

Lonsdale, C., Rosenkranz, R.R., Peralta, L.R., Bennie, A., Fahey, P., \& Lubans, D.R. (2013). A systematic review and meta-analysis of interventions designed to increase moderate-to-vigorous physical activity in school physical education lessons. Preventive Medicine, 56(2), 152-161. doi: 10.1016/j.ypmed.2012.12.004

Mawer, M. (2014). Effective teaching of physical education. Routledge.

McCaughtry, N., Martina, J., Hodges Kulinnab, P., \& Cothranc, D. (2006). What makes teacher professional development work? The influence of instructional resources on change in physical education. Journal of In-service Education, 32(2), 221-235. doi: 10.1080/13674580600650997 
Montessori, M. (1995). The Montessori mthod. Thoemmes Press.

Morton, K.L., Atkin, A.J., Corder, K., Suhrcke, M., \& van Sluijs, E.M.F. (2016). The school environment and adolescent physical activity and sedentary behaviour: A mixed-studies systematic review. Obesity Reviews, 17(2), 142-158. doi: 10.1111/obr.12352

MSES - Ministry of Science, Education and Sport. (2008a). Državni pedagoški standardi. [Croatian National Educational Standards. In Croatian.] Retrieved from https://www.hrstud.unizg.hr/_download/repository/Drzavni_pedagoski_ standardi.pdf on May 11, 2019.

MSES - Ministry of Science, Education and Sport. (2006). Nastavni plan i program za osnovnu školu (HNOS). [Primary school education curriculum. In Croatian.] Retrieved from https://www.azoo.hr/images/AZOO/Ravnatelji/RM/ Nastavni_plan_i_program_za_osnovnu_skolu_-_MZOS_2006_pdf on May 11, 2019.

MSES - Ministry of Science, Education and Sport. (2008b). The pedagogical standard of primary education in the Republic of Croatia. [In Croatian.] Narodne novine=Official Gazette, 63/2008. Retrieved April 26, 2020, from https://narodne-novine.nn.hr/clanci/sluzbeni/2008_06_63_2129.html on May 11, 2019.

Pažur, M. (2019). Materijalni uvjeti i opremljenost nastavno-sportskih dvorana slavonske regije. [Material conditions and equipment of the educational and sports gymnasia in the Slavonia region. In Croatian.] Osijek: Josip Juraj Strossmayer University Osijek. Retrieved from https://repozitorij.foozos.hr/islandora/object/foozos:905 on May 11, 2019.

Stevanović, R., Capak, K., \& Benjak, T. (Eds). (2016). Croatian health statistics yearbook 2015. Retrieved from https:// www.hzjz.hr/wp-content/uploads/2017/09/Ljetopis_2015_IX.pdf on May 11, 2019.

Tsangaridou, N. (2017). Early childhood teachers' views about teaching physical education: Challenges and recommendations. Physical Education and Sport Pedagogy, 22(3), 283-300. doi: 10.1080/17408989.2016.1192593

WHO - World Health Organization. (2004). Global strategy on diet, physical activity and health. Retrieved from https://apps.who.int/iris/bitstream/handle/10665/43035/9241592222_eng.pdf on May 11, 2019

WHO - World Health Organization. (2010). Global recommendations on physical activity for health. Geneva: WHO. Retrieved from https://www.who.int/dietphysicalactivity/factsheet_recommendations/en/ on May 11, 2019

Xiang, P., McBride, R.E., \& Gao, Z. (2011). Student teachers' use of instructional choice in physical education. Research Quarterly for Exercise and Sport, 82(3), 482-490. doi: 10.1080/02701367.2011.10599781

Submitted: December 17, 2019

Accepted: May 11, 2020

Published Online First: May 29, 2020

Correspondence to:

Slaven Krtalić, Ph.D.

Croatian Institute of Public Health, Croatia

Rockefeller Street 7,

10000, Zagreb, Croatia

E-mail: skrtalic@gmail.com

\footnotetext{
Acknowledgments

The authors gratefully acknowledge the Ministry of Science, Education and Sports as well as the Education and Teacher Training Agency, for their support in the implementation of this project. Grateful thanks are extended to Matija Gubec Primary School principal Ljiljana Klinger, for the organization of the meeting with 120 school principals where the project goals and activities were thoroughly discussed. Also, to her school team Spomenka Mlinarić, Marija Mahalek and Marko Korbar for their help with the education of other school-teams.

Sincere appreciation is expressed to the Croatian Ministry of Health for their financial support in procuring Sets of kinesiological aids.

We kindly thank the Croatian Institute of Public Health employee, IT team, especially Borna Pleše, for technical support and help with statistical analysis.

Lastly, we thank all school team members included in this project for making this study possible, for their valuable time, collaboration, and willingness to fill in the questionnaires.
}

\section{Funding}

The Sets of kinesiological aids in the Polygon project were funded by the Croatian Ministry of Health. 